AperTO - Archivio Istituzionale Open Access dell'Università di Torino

\title{
Effect of different coatings in preventing deterioration and preserving the quality of fresh-cut nectarines (cv Big Top)
}

\section{This is the author's manuscript}

Original Citation:

Availability:

This version is available http://hdl.handle.net/2318/138839

since 2015-12-01T14:20:15Z

Published version:

DOI:10.1080/19476337.2012.745096

Terms of use:

Open Access

Anyone can freely access the full text of works made available as "Open Access". Works made available under a Creative Commons license can be used according to the terms and conditions of said license. Use of all other works requires consent of the right holder (author or publisher) if not exempted from copyright protection by the applicable law. 
Effect of different coating in preventing deterioration and preserving the quality of fresh-cut nectarines cv Big Top

V. Chiabrando*, G. Giacalone

Department of Arboriculture, Turin University, Via L. da Vinci 44, 10095 Grugliasco (TO), Italy.

*Corresponding author: Tel +390116708938. Fax +390116708658.

Email: valentina.chiabrando@unito.it

Fresh-cut nectarines are very perishable product, and thus have a short shelf-life. In this study, minimally processed nectarines (cv Big Top) were treated with chitosan (20 g/L), sodium alginate $(20 \mathrm{~g} / \mathrm{L})$ and Chitoplant ${ }^{\circledR}(20 \mathrm{~g} / \mathrm{L})$, sealed in polypropylene plastic bags and stored at $4^{\circ} \mathrm{C}$ for 5 days. Effects of the coatings on nectarine slices shelf-life and qualitative attributes were evaluated by investigating changes in colors, browning potential, total soluble solids content and titratable acidity. Changes in quality parameters were lower in coated samples as compared with the control. The alginate coatings were effective on delaying the evolution of the parameters related to postharvest ripening, such as color (Hue, $\left.\mathrm{L}^{*}\right)$ and loss of acidity. The application of sodium alginate coating could be used to reduce deteriorative processes, maintain quality and improve the shelf-life of fresh-cut nectarine stored at $4^{\circ} \mathrm{C}$.

Keywords: fresh-cut nectarines; edible coating, quality attributes.

Introduction

Minimal processing has been defined as a combination of procedures, such as washing, sorting, trimming, peeling, and slicing or chopping, that do not affect the fresh-like quality of the food. Ready-to-eat fruits and vegetable market has rapidly grown in recent years due to the health benefits associated with these foods because of busy lifestyles, increasing purchasing power, and 
increasingly health-conscious consumers. Nevertheless, because the tissular integrity of fruits is more easily altered during processing, ready-to-use commodities are more perishable than the original materials (Oms-Oliu et al., 2010).

The main factors affecting the loss of consumer acceptability are discoloration, enzimatic browning, dryness and texture loss (Pérez-Gago, González-Aguilar \& Olivas, 2005). These parameters determine the visual appearance (Pace, Cefola, Renna \& Attolico, 2011). For this reason the fruit processing industry requires the development of techniques able to keep safe shelf-life and preserve the original visual and organoleptic fresh-like characteristics of fresh-cut produces.

The commercial success of fresh-cut peach and nectarine slices has been limited due to their short shelf-life, because of cut surface browning, excessive flesh softening and pit cavity breakdown (Gorny, Hess-Pierce \& Kader, 1998). For these reasons makes essential for finding treatments to slow down the browning and ripening process and prolonging their shelf-life. Several treatments have been studied in order to maintain quality and to extend the shelf-life of fresh-cut peach and nectarine like heat treatment (Steiner et al., 2006), chemical treatments (Gorny, HessPierce \& Kader, 1999; Costa da Costa, Antunes, Valmor Rombaldi \& Arocha, 2011; Zhu, Zhou, Zhu \& Guo, 2009), modified atmosphere packaging (Zoffoli, Rodriguez, Aldunce \& Crisosto, 1997; Palmer-Wright \& Kader, 1997) and edible coatings application (Du, 1997; Ruoyi, Zhifang \& Zhaoxin, 2005).

Edible coatings, a new strategy used to extend shelf-life and to improve food quality of whole fruits and fresh-cut fruits, have been applied to many products. Coatings on minimally processed products create a semipermeable barrier to external elements that can reduce moisture loss, solutes migration, respiration and oxidative reaction rates (Barbosa, Dias de Mello Castanho \& Rodrigues Monteiro, 2011; Vargas, Pastor, Chiralt, McClements \& González- Martínez, 2008). Chitosan has been one of the most promising coating materials for fruits because of its good filmforming property, broad antimicrobial activity, and excellent compatibility with other substances. 
Furthermore, chitosan films are tough, highly transparent, long-lasting and flexible (Cé, Caciano \& Brandelli, 2012). Other popular edible coating formulations were polysaccharide-based like alginate or protein-based polymers (Diaz-Mula, Serrano \& Valero, 2011). Maintenance of fruit quality has been achieved by using chitosan in peach ( $\mathrm{Li} \& \mathrm{Yu}, 2001$ ), strawberries (Vu, Hollingsworth, Leroux, Salmieri \& Lacroix, 2011) and papaya (Asgar, Tengku, Kamaruzaman \& Yasmeen, 2011), pectin coating in melon (Ferrari, Sarantópoulos, Carmello-Guerreiro \& Hubinger, 2011), alginate in apple (Rojas-Graü, Tapia, Rodríguez, Carmona \& Martin-Belloso, 2007; Olivas, Mattinson \& Barbosa-Cánovas, 2007) and in papaya (Tapia et al., 2008).

The objective of this work were to evaluate the effectiveness of different coatings in order to prolong shelf-life of nectarine slices, and to study the effect of the best treatment on the quality of fresh-cut nectarine slices stored in modified atmosphere packaging, as the commercial practice.

Materials and methods

Material

Nectarines (Prunus persica (L.) Batsch., cv Big Top) were harvested at commercial maturity, and stored $\left(4^{\circ} \mathrm{C}\right.$ and $\left.95 \% \mathrm{RH}\right)$ before processing. The fruits were peeled, cored and cut into 5-mm-thick slices using a hand-operated slicer.

Methods

\section{Sample preparation}

Three different coating solutions were prepared: (1) $20 \mathrm{~g} / \mathrm{L}$ chitosan (90-95\% of deacetylated degree and 90-100 mPa.s of viscosity, Sigma-Aldrich Co., Steinhein, Germany), (2) 20 g/L sodium

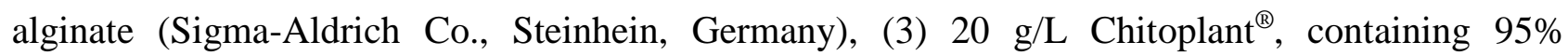
chitosan, 2.5\% boron and $2.5 \%$ zinc (Agritalia, Italy), a commercial chitosan formulation. Nectarines slices used as controls were not treated with coating. 
(1) Film-forming solutions were prepared by dissolving chitosan (20 g/L) powders in an aqueous solution of $20 \mathrm{~g} / \mathrm{L}$ citric acid. Then, the solution was added with $500 \mathrm{ml} / \mathrm{L}$ glycerol and $1,5 \mathrm{ml} / \mathrm{L}$ Tween 20 to improve the wettability (Duan, Wu, Strik \& Zhao, 2011). The mixture was homogenized for $1 \mathrm{~min}$ and stirred in a $60{ }^{\circ} \mathrm{C}$ water bath for $30 \mathrm{~min}$, followed by cooling to room temperature.

(2) Film-forming solutions were prepared by dissolving sodium alginate $(20 \mathrm{~g} / \mathrm{L})$ powders in deionized water while heating on a stirring hot plate for $10 \mathrm{~min}$ at $70{ }^{\circ} \mathrm{C}$ until the mixture became clear (Chiumarelli, Ferrari, Sarantópoulos \& Hubinger, 2011). Coating solutions also contained glycerol (15 ml/L) as an emulsifier and calcium chloride (20 g/L) (Sigma-Aldrich Co., Steinhein, Germany). Calcium chloride was used to induce crosslinking reaction (Rojas-Graü, Tapia, Rodríguez, Carmona \& Martin-Belloso, 2007; Tapia et al., 2008 ).

(3) Film-forming solutions were prepared by dissolving Chitoplant ${ }^{\circledR}(20 \mathrm{~g} / \mathrm{L})$ powders in deionized water with continuous shaking until the solution became clear. No plasticizer was added.

Slices were immersed in the coating solutions for $1 \mathrm{~min}$ at $20^{\circ} \mathrm{C}$ and were then allowed to drip off. Fruits dipped in sodium alginate based coating, in addition, were immersed in calcium chloride for $30 \mathrm{~s}$. Control fruits were dipped in distilled water.

25 slices were randomly selected and packaged in polypropylene plastic bags $(20 \mathrm{~cm} \times 30 \mathrm{~cm}$ size and $90 \mu \mathrm{m}$ thickness) with $50 \mathrm{~cm} 3 \mathrm{O} 2 / \mathrm{m} 2 / \mathrm{bar} /$ day, $150 \mathrm{~cm} 3 \mathrm{CO} 2 / \mathrm{m} 2 / \mathrm{bar} /$ day and 2.8 $\mathrm{g} / \mathrm{m} 2 / \mathrm{bar} /$ day water vapor transmission rate (I.Plast, Italy). The packages were completely sealed (UNIMEC packaging systems, Italy) and than were stored at $4{ }^{\circ} \mathrm{C}$ and $95 \% \mathrm{RH}$ in darkness for 5 days.

\section{Analysis}

\section{Gases composition}


The concentrations of oxygen and carbon dioxide inside the packages were monitored daily by sampling $(0.5 \mathrm{ml})$ the headspace using a CANAL 121 (Vizag, Gas Analysis, France). A syringe was inserted into the package through a rubber seal placed on the film. Gases were analysed with an electrochemical sensor for $\mathrm{O}_{2}$ level and an infrared sensor for $\mathrm{CO}_{2}$ level. The instrument was calibrated towards air. Results were expressed as $\mathrm{kPa}$ of $\mathrm{O}_{2}$ and $\mathrm{CO}_{2}$ inside the bags.

\section{Quality measurements}

Color analysis were performed at $0,1,2$ and 5 days of cold storage at $4{ }^{\circ} \mathrm{C}$.

$L^{*}, a^{*}$, and $b^{*}$ values were determined at two points along each side of the cut surface using a Minolta chroma-meter (CR400; Minolta, Ramsey, NJ, USA). The flesh color was also expressed as whiteness index $\left(\mathrm{WI}=100-\left[\left(100-\mathrm{L}^{*}\right) 2+\left(\mathrm{a}^{*}\right) 2+\left(\mathrm{b}^{*}\right) 2\right] 1 / 2\right)$ according to Bolin and Huxsoll (1991).

Quality analysis were performed at 0 on the nectarines whitout coating and after 5 days of cold storage at $4^{\circ} \mathrm{C}$ in all the treatments. Total soluble solids content (TSS) was determined in the juice from 25 slices with a digital refractometer Atago PR-101 (Atago, Japan) at $20{ }^{\circ} \mathrm{C}$ and results expressed as ${ }^{\circ}$ Brix. Titratable acidity (TA) was determined by titration with $0.1 \mathrm{~N} \mathrm{NaOH}$ up to $\mathrm{pH}$ 8.1, using $10 \mathrm{ml}$ of diluted juice in distilled $\mathrm{H}_{2} \mathrm{O}$ and results were expressed as meq/L.

\section{Browning potential}

Browning potential was determined according to the method of Arias, Gonzalez, Lopez-Buesa and Oria (2008) at day 0, and after 1 and 5 days of storage. The extract was obtained as followed: nectarine slices $(25 \mathrm{~g})$ from each treatment were homogenized for 2 minutes at 13,500 rpm with an Ultra-Turrax T25 (IKAs WERKE, Germany), the homogenates were centrifuged (Centrifuge AVANTITM J-25, Beckman Instruments Inc., Fullerton, Calif., U.S.A.) at $4000 \mathrm{rpm}$ for $10 \mathrm{~min}$ and the supernatant was filtered through Whatman 4 filter paper (Whatman Intl., U.K.). The absorbance 
of the clear juice was then measured spectrophotometrically (Hitachi, U-5100, Japan) at $440 \mathrm{~nm}$ to determine browning potential (BP). This measurement was replicated three times.

\section{Statistical analysis}

The basic experimental design consisted of three coating treatments, each having three replicates. In sliced nectarine measures, a package contained 25 slices, which was equivalent to two nectarines, was considered a replicate. Data were analyzed by analysis of variance using statistical procedures of the STATISTICA ver. 6.0 (Statsoft Inc., Tulsa, OK, USA). The sources of variance being coating treatments. Tukey's test HSP (honestly significant differences) was used to determine significant differences among treatment means. Means values were considered significantly different at $P \leq$ 0.05 .

Results and discussion

\section{Gases composition}

Significant differences were observed between coated and uncoated nectarine slices regarding the composition of $\mathrm{O}_{2}$ and $\mathrm{CO}_{2}$ in the head space along the evaluated period (Fig. 1-2). Higher $\mathrm{O}_{2}$ levels were found in alginate coating slices, lower in chitosan coating slices. This result, probabily depend on the different barrier effect and mechanical properties of the coatings solutions used (Chiumarelli \& Hubinger, 2012). Moreover, the application of coatings in fresh-cut products can create a modified atmosphere around each piece, reducing the respiration rate and the metabolic processes (Rojas-Graü, Tapia \& Martín-Belloso, 2008).

$\mathrm{CO}_{2}$ production was lower in alginate-coated slices with respect to control ones, especially in the first 2 days of storage (Fig. 2), in agreement with previous reports in peaches coated with chitosan, methylcellulose or alginate (Li \& Yu 2001; Maftoonazad, Ramaswamy \& Marcotte, 2008). Alginate coating acts as barrier to gas exchange, so there is less oxygen available for plant 
tissues respiration, resulting in lower release of carbon dioxide by the product, and, consequently, reducing the metabolic processes (Rojas-Graü, Tapia, Rodríguez, Carmona \& Martin-Belloso, 2007). On the contrary, $\mathrm{CO}_{2}$ production was significantly higher in Chitoplant ${ }^{\circledR}$ treated slices.

\section{Quality measurements}

Cut surface browning is a major problem for several minimal processed fruits. On non-treated samples a darkening effect on the color of cut slices was noted, when compared to treated samples, in according with instrumental color evaluation (Hue angle).

During storage, a reduction in Hue angle was observed in all the treatments (Fig. 3) and in control slices. The highest values were obtained in slices treated with sodium alginate, with final value of 95.12, showing a reduction of the ripening process.

No significant differences were observed in those slices treated with $2 \%$ chitosan, $2 \%$ chitoplant and control respect to color evolution during cold storage. A sharp decrease in Hue angle would indicate an over-ripe and senescence process of fruit, which is considered as detrimental (Rojas-Graü, Tapia \& Martín-Belloso, 2008). On the contrary, the alginate coated fruits (with higher Hue angle) maintained the typical bright color of recently processed fruits.

Fruit color is crucial in purchase decisions, especially if the product is packaged and cannot be touched or smelled. During storage the L* value decreased for all the control and treated fruits (Fig. 4). However, a smaller decrease was observed for the fresh-cut fruit treated with sodium alginate and control. Lightness was better preserved by the treatment with sodium alginate coating. On the contrary, chitosan coating slices showed the lowest $\mathrm{L}^{*}$. The lower $\mathrm{L}^{*}$ level could be also correlated with the reduction of $\mathrm{O}_{2}$ and increase of $\mathrm{CO}_{2}$ inside the packages and with a greater deterioration of the fruit (Fig. 1). A rapid deterioration of the fruit involved an increase in respiration rate and enzymatic metabolic processes that led to a loss of quality of fresh-cut produce (Gonzalez-Aguilar et al., 2009). 
The $b *$ value was used to estimate changes in the yellow color during the storage time (Gonzalez-Aguilar et al., 2009). Control fruit showed the lowest $b *$ values, high values of coating fruits indicated that chitosan and alginate treatments were able to maintain the highest $b *$ values during the storage time. The severity of surface whitening for the coated and uncoated nectarine slices was quantitatively expressed by WI scores at different treatments (Fig. 6). Higher WI scores indicated greater development of surface whiteness (Gounga, Xu, Wang \& Yang, 2008). For uncoated slices, the WI score range from 49.4 to 47.1 while the chitosan coating showed the lowest WI score of 39.11 , at the end of storage period. This result is related with $\mathrm{L}^{*}$ values and with the result of previous work (Raybaudi-Massilia, Mosqueda-Melgar \& Martín-Belloso, 2008; Vargas et al., 2009) and could be due to the film forming effect of chitosan on surface pores of the samples, which limits water losses. Changes in WI was also reported by Aguayo, Allende and Artés (2003) in "Piel de sapo" melon and others varieties, indicating that WI decreased when translucency injury increased on fresh-processed melon, as a consequence of a physiological disorder characterized by dark and glassy flesh.

TSS at harvest was $8.2^{\circ}$ Brix with significant effect $(P \leq 0.05)$ of coating treatments during storage on nectarine slices. The Chitoplant ${ }^{\circledR}$ coating induced a significant $(P \leq 0.05)$ decrease in TSS content and titratable acidity values comapred to chitosan treated slices. The faster decrease in acidity gave rise to a faster senescence (Asgar, Tengku, Kamaruzaman \& Yasmeen, 2011). On the contrary, the chitosan and alginate coatings were significantly $(P \leq 0.05)$ effective in delaying the loss of acidity, which occurred during cold storage (titratable acidity at harvest was 97.98 meq/l).

The levels of titratable acidity were correlated with the antibrowning efficacy of the treatments. Han, Zhao, Leonard and Traber (2004) reported that in raspberry and strawberry, the chitosan coatings slowed down the changes in titratable acidity, effectively delaying fruit ripening. The effects of edible coating on decreasing acidity losses have been also found in chitosan and alginate coated peaches ( $\mathrm{Li} \&$ Yu 2001; Maftoonazad, Ramaswamy \& Marcotte, 2008). The effect of 
coating on acidity retention could be a result of the lower respiration rate found in coated fruits, since organic acids are substrates for many reactions during aerobic respiration in plant cell. In chitosan coating significant $(P \leq 0.05)$ higher acidity values are also due to the effect of citric acid utilized for film-forming solution.

Table 1 shows $\mathrm{pH}$ variations during storage for control and coated samples. As expected, since coated fruits showed less variation in titrable acidity, the associated variation in their $\mathrm{pH}$ was also relatively lower and no significant ( $\mathrm{pH}$ at harvest was 5.48). At the end of storage, control nectarines had significant higher $\mathrm{pH}$ than coated fruits, confirming some previous results (Togrul \& Arslan, 2004).

\section{Browning Potential}

Browning potential was monitored in all the samples. An increase in browning potential was found throughout storage (Fig.7) in according with other works (Martin-Diana et al., 2007; Castaner, Gil, Ruíz \& Artes 1999). Control samples presented the highest and Chitoplant ${ }^{\circledR}$ the lowest values (Fig. 7). The application of Chitoplant ${ }^{\circledR}$ coating proved to be the treatment that was the most effective in reducing browning index of nectarine slices. This could be due to the inactivation of the enzymes by the use of coating and to the lower viscosity of Chitoplant ${ }^{\circledR}$ (Martin-Diana et al., 2007, Romanazzi et al., 2009).

Chitosan coatings were able to decrease browning of fruit by reducing polyphenol oxidase and peroxidase activities, these changes were directly related to color changes of the flesh of different fruits and vegetables. A chitosan coating form a protective barrier on the surface of the fruit and reduce the supply of oxygen for enzymatic oxidation of phenolics (Zhang \& Quantick, 1998).

\section{Conclusion}


The use of edible coatings can help maintain desirable quality characteristics of fresh-cut Big Top nectarine slices. The coated slices maintained their initial color during the refrigerated storage, in particular, the samples treated with alginate coating. Moreover, coatings reduced browning potential and decay of fresh-cut nectarine, in particular with the use of Chitoplant ${ }^{\circledR}$. The alginate coatings were effective on delaying the evolution of the parameters related to postharvest ripening, such as color and loss of acidity, which could be explained by the gas barrier provided by the coatings creating a modified atmosphere in the fruit. On the contrary, chitosan coating was not effective on delaying color browning, in particular the lightness and the whitness. According to the results obtained in this study, sodium alginate $(20 \mathrm{~g} / \mathrm{L})$ and Chitoplant ${ }^{\circledR}$ appears to be a promising conservation alternative for fresh-cut nectarine.

\section{References}

Asgar, A.M., Tengku, M.M., Kamaruzaman, S., \& Yasmeen, S. (2011). Effect of chitosan coatings on the physicochemical characteristics of Eksotika II papaya (Carica papaya L.) fruit during cold storage. Food Chemistry, 124, 620-626.

Aguayo, E., Allende, A., \& Artés, F. (2003). Keeping quality and safety of minimally fresh processed melon. European Food Research and Technology, 216, 494-499.

Arias, E., Gonzalez, J., Lopez-Buesa, P., \& Oria, R. (2008) Optimization of processing of fresh-cut pear. Journal of the Science of Food and Agriculture, 88, 1755-1763.

Barbosa, L.N., Dias de Mello Castanho A.R., \& Rodrigues Monteiro, A. (2011). Influence of temperature and edible coating on the physical and chemical parameters and sensory acceptance of fresh-cut organic carrots. CyTA - Journal of Food , 1, 31-36.

Bolin, H.R., \& Huxsoll, C.C. (1991). Control of minimally processed carrot (Daucus carota) surface discolouration caused by abrasion peeling. Journal of Food Science, 56, 416-418. 
Castaner, M., Gil, M.I., Ruíz, M.V. \& Artes, F. (1999). Browning susceptibility of minimally processed Baby and Romaine lettuces. European Food Research and Technology, 209, 52-56.

Cé, N., Caciano, P.Z., \& Brandelli, N.A. (2012) Antimicrobial activity of chitosan films containing nisin, peptide P34, and natamycin. CyTA - Journal of Food, 10, 1, 21-26.

Chiumarelli, M., Ferrari, C.C., Sarantópoulos, C.I.G.L., \& Hubinger, M.D. (2011). Fresh cut 'Tommy Atkins' mango pre-treated with citric acid and coated with cassava (Manihot esculenta Crantz) starch or sodium alginate. Innovative Food Science and Emerging Technologies, 12, 381387.

Chiumarelli, M., \& Hubinger, M.D. (2012). Stability, solubility, mechanical and barrier properties of cassava starch e Carnauba wax edible coatings to preserve fresh-cut apples. Food Hydrocolloids 28, 59-67.

Costa da Costa, A., Antunes, P.L., Valmor Rombaldi, C., Arocha, G.M. (2011). Control of enzymatic browning and flesh firmness in fresh-cut peaches. Ciencia Rural, 41, 1094-1101.

Díaz-Mula, H.M., Serrano, M. \& Valero, D. (2011). Alginate coatings preserve fruit quality and bioactive compounds during storage of sweet cherry fruit. Food Bioprocess Technology, in press, DOI 10.1007/s11947-011-0599-2

Du, J. (1997). Effects of chitosan coating on the storage of peach, japanese pear and kiwifruit. Journal of the Japanese Society for Horticultural Science, 66, 15-22.

Duan, J., Wu, R., Strik, B.C., \& Zhao, Y. (2011). Effect of edible coatings on the quality of fresh blueberries (Duke and Elliott) under commercial storage conditions. Postharvest Biology and Technology, 59, 71-79.

Ferrari, C.C., Sarantópoulos, C., Carmello-Guerreiro, S.M. \& Hubinger, M.D. (2011).Effect of osmotic dehydration and pectin edible coatings on quality and shelf life of fresh-cut melon. Food Bioprocess Technology, in press, DOI 10.1007/s11947-011-0704-6. 
Gonzalez-Aguilar, G.A., Valenzuela-Soto, E., Lizardi-Mendoza, J., Goycoolea, F., MartinezTellez, M.A.,Villegas-Ochoa, M.A., Monroy-Garcia, I.M., \& Ayala-Zavala, J.F. (2009). Effect of chitosan coating in preventing deterioration and preserving the quality of fresh-cut papaya 'Maradol'. Journal of the Science of Food and Agriculture, 89, 15-23.

Gorny, J.R., Hess-Pierce, B., \&. Kader, A.A. (1998). Effects of fruit ripeness and storage temperature on the deterioration rate of fresh-cut peach and nectarine slices. HortScience, 33, 110113.

Gorny, J.R., Hess-Pierce, B., \&. Kader, A.A. (1999). Quality changes in fresh-cut peach and nectarine slices as affected by cultivar, storage atmosphere and chemical treatments. Journal of Food Science, 64, 429-432.

Gounga, M.E.,. Xu, S.Y, Wang, Z., \& Yang, W.G. (2008). Effect of whey protein isolate-pullulan edible coatings on the quality and shelf life of freshly roasted and freeze-dried chinese chestnut. Journal of Food Science, 73, 155-161.

Han, C., Zhao, Y., Leonard, S.W., \& Traber, M.G. (2004). Edible coatings to improve storability and enhance nutritional value of fresh and frozen strawberries (Fragaria ananassa) and raspberries (Rubus idaeus). Postharvest Biology and Technology, 33, 67-78.

Li, H., \& Yu, T. (2001). Effect of chitosan coating on incidence or brown rot, quality and physiological attributes for postharvest peach fruit. Journal of the Science of Food and Agriculture, $81,269-274$.

Maftoonazad, N., Ramaswamy, H.S., \& Marcotte, M. (2008). Shelflife extension of peaches through sodium alginate and methyl cellulose edible coatings. International Journal of Food Science \& Technology, 43, 951-957.

Martin-Diana, A.B., Rico D., Barry-Ryan, C., Frias, J.M, Henehan, G.T.M. \& Barat J.M. (2007). Efficacy of steamer jet-injection as alternative to chlorine in fresh-cut lettuce. Postharvest Biology and Technology, 45, 97-107. 
Olivas, G.I., Mattinson, D.S., \& Barbosa-Cánovas, G.V. (2007). Alginate coatings for preservation of minimally processed 'Gala' apples. Postharvest Biology and Technology, 45, 89-96.

Oms-Oliu, G., Rojas-Graü, M.A, González, L., Varela, P., Soliva-Fortuny, R., Hernando, M.I., Pérez Munuera, I., Fiszman, S., \& Martín-Belloso, O. (2010). Recent approaches using chemical treatments to preserve quality of fresh-cut fruit: a review. Postharvest Biology and Technology, 57, $139-148$.

Pace, B., Cefola, M., Renna, F, \& Attolico, G. (2011). Relationship between visual appearance and browning as evaluated by image analysis and chemical traits in fresh-cut nectarines. Postharvest Biology and Technology, 61, 178-183.

Palmer-Wright, K., \& Kader, A.A. (1997). Effect of controlled-atmosphere storage on the quality and carotenoid content of sliced persimmons and peaches. Postharvest Biology and Technology, 10, 89-97.

Pérez-Gago, M.B., González-Aguilar, G.A., \& Olivas, G.I. (2005). Edible coatings for fruits and vegetables. Stewart Postharvest Review, 6, 1-14.

Raybaudi-Massilia, R.M., Mosqueda-Melgar, J., \& Martín-Belloso, O. (2008). Edible alginatebased coating as carrier of antimicrobials to improbe shelf-life and safety of fresh-cut melon. International Journal of Food Microbiology, 121, 313-327.

Rojas-Graü, M.A., Tapia, M.S., Rodríguez, F.J., Carmona, A.J., \& Martin-Belloso, O. (2007). Alginate and gellan-based edible coatings as carriers of antibrowning agents applied on fresh-cut Fuji apples. Food Hydrocolloids, 21, 118-127.

Rojas-Graü, M.A., Tapia, M.S., \& Martín-Belloso, O. (2008). Using polysaccharidebased edible coatings to maintain quality of fresh-cut fuji apples. Food Science \& Technology, 41, 139-147.

Romanazzi, G., Mlikota Gabler, F., Margosan, D.A., Mackey, B.F., \& Smilanick, J.L. (2009). Effect of acid used to dissolve chitosan on its film forming properties and its ability to control postharvest grey mold of table grape. Phytopathology, 99, 1028-1036. 
Ruoyi, K., Zhifang, Y., \& Zhaoxin, L. (2005). Effect of coating and intermittent warming on enzymes, soluble pectin substances and ascorbic acid of Prunus persica ( $\mathrm{Cv}$. Zhonghuashoutao) during refrigerated storage. Food Research International, 38, 331-336.

Steiner, M., Abreu, L., Correia, S., Beirao-da-Costa, E., Leitao, M., Beirao-da-Costa, J.E., \& Moldao-Martins, M. (2006). Metabolic response to combined mild heat pre-treatments and modified atmosphere packaging on fresh-cut peach. European Food Reserch and Technology, 222, $217-222$

Tapia, M.S., Rojas-Graü, M.A., Carmona, A., Rodríguez, F.J., Soliva-Fortuny, R., \& MartinBelloso, O. (2008). Use of alginate- and gellan-based coatings for improving barrier, texture and nutritional properties of fresh-cut papaya. Food Hydrocolloids, 22, 1493-1503.

Togrul, H., \& Arslan, N. (2004). Extending shelf-life of peach and pear by using CMC from sugar beet pulp cellulose as a hydrophilic polymer in emulsions. Food Hydrocolloids, 18, 215-226.

Vargas, M., Pastor, C., Chiralt, A., McClements, D.J., \& González- Martínez, C. (2008). Recent advances in edible coatings for fresh and minimally processed fruits. Critical Reviews in Food Science and Nutrition, 48, 496-511.

Vargas, M., Chiralt, A., Albors, A., \& González-Martínez, C. (2009). Effect of chitosan-based edible coatings applied by vacuum impregnation on quality preservation of fresh-cut carrot. Postharvest Biology and Technology, 51, 263-271.

Vu, K.D., Hollingsworth, R.G., Leroux, E., Salmieri, S., \& Lacroix, M. (2011). Development of edible bioactive coating based on modified chitosan for increasing the shelf life of strawberries. Food Research International, 44, 198-203.

Zhang, D.L., \& Quantick, P.C. (1998). Antifungal effects of chitosan coating on fresh strawberries and raspberries during storage. The Journal of Horticultural Science and Biotechnology, 73, 763767. 
Zhu, L.Q., Zhou, J., Zhu, S.H. \& Guo, L.H. (2009). Inhibition of browning on the surface of peach slices by short-term exposure to nitric oxide and ascorbic acid. Food Chemistry, 114, 174-179.

Zoffoli, J.P., Rodriguez, J., Aldunce, P., \& Crisosto, C.H. (1997). Development of high concentration carbon dioxide modified atmosphere packaging systems to maintain peach quality. Proceedings of the International Controlled Atmosphere Research Conference, Davis, California, $v$. $3,37-45$. 
Table

Table 1. Changes in total soluble solid content $\left({ }^{\circ}\right.$ Brix), titratable acidity (meq/l) and $\mathrm{pH}$ of nectarines coated with Chitoplant ${ }^{\circledR}(20 \mathrm{~g} / \mathrm{L})$, chitosan $(20 \mathrm{~g} / \mathrm{L})$ and sodium alginate $(20 \mathrm{~g} / \mathrm{L})$ after cold storage $\left(4^{\circ} \mathrm{C}\right.$ and $\left.95 \% \mathrm{RH}\right)$.

\begin{tabular}{llccc}
\hline days of storage & treatment & \multicolumn{3}{c}{ quality parameters } \\
\hline & & total soluble solids & titratable acidity & $\mathrm{pH}$ \\
\hline day 0 & control & $8.2 \pm 0.2$ & $47.98 \pm 0.3$ & $5.48 \pm 0.3$ \\
\hline day 5 & control & $7.8 \pm 0.2 \mathrm{~b}$ & $27.73 \pm 2.5 \mathrm{c}$ & $5.79 \pm 0.5 \mathrm{a}$ \\
& chitosan & $8.7 \pm 0.1 \mathrm{a}$ & $44.47 \pm 3.2 \mathrm{a}$ & $5.56 \pm 0.3 \mathrm{~b}$ \\
& chitoplant & $6.8 \pm 0.1 \mathrm{bc}$ & $22.34 \pm 2.7 \mathrm{c}$ & $5.63 \pm 0.6 \mathrm{~b}$ \\
& alginate & $7.4 \pm 0.2 \mathrm{~b}$ & $36.79 \pm 2.4 \mathrm{~b}$ & $5.54 \pm 0.5 \mathrm{~b}$ \\
\hline
\end{tabular}

Data are the mean \pm SE $(n=25)$. Mean values followed by the same letter in column are not significantly different at $P \leq 0.05$ level.

Fig. 1. Evolution of $\mathrm{O}_{2}(\mathrm{KPa})$ during cold storage on nectarines coated with Chitoplant ${ }^{\circledR}(20 \mathrm{~g} / \mathrm{L})$, chitosan $(20 \mathrm{~g} / \mathrm{L})$ and sodium alginate $(20 \mathrm{~g} / \mathrm{L})$.

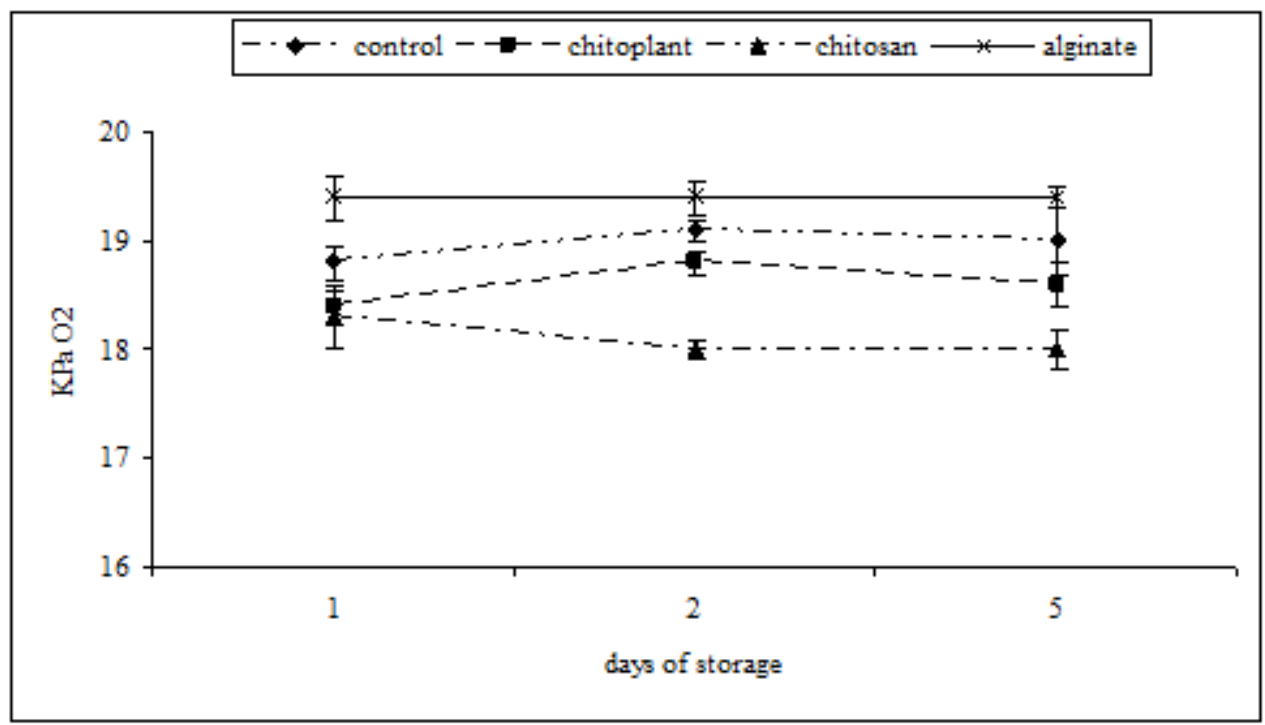


Fig. 2. Evolution of $\mathrm{CO}_{2}$ concentration $(\mathrm{KPa})$ during cold storage on nectarines coated with Chitoplant $^{\circledR}(20 \mathrm{~g} / \mathrm{L})$, chitosan $(20 \mathrm{~g} / \mathrm{L})$ and sodium alginate $(20 \mathrm{~g} / \mathrm{L})$.

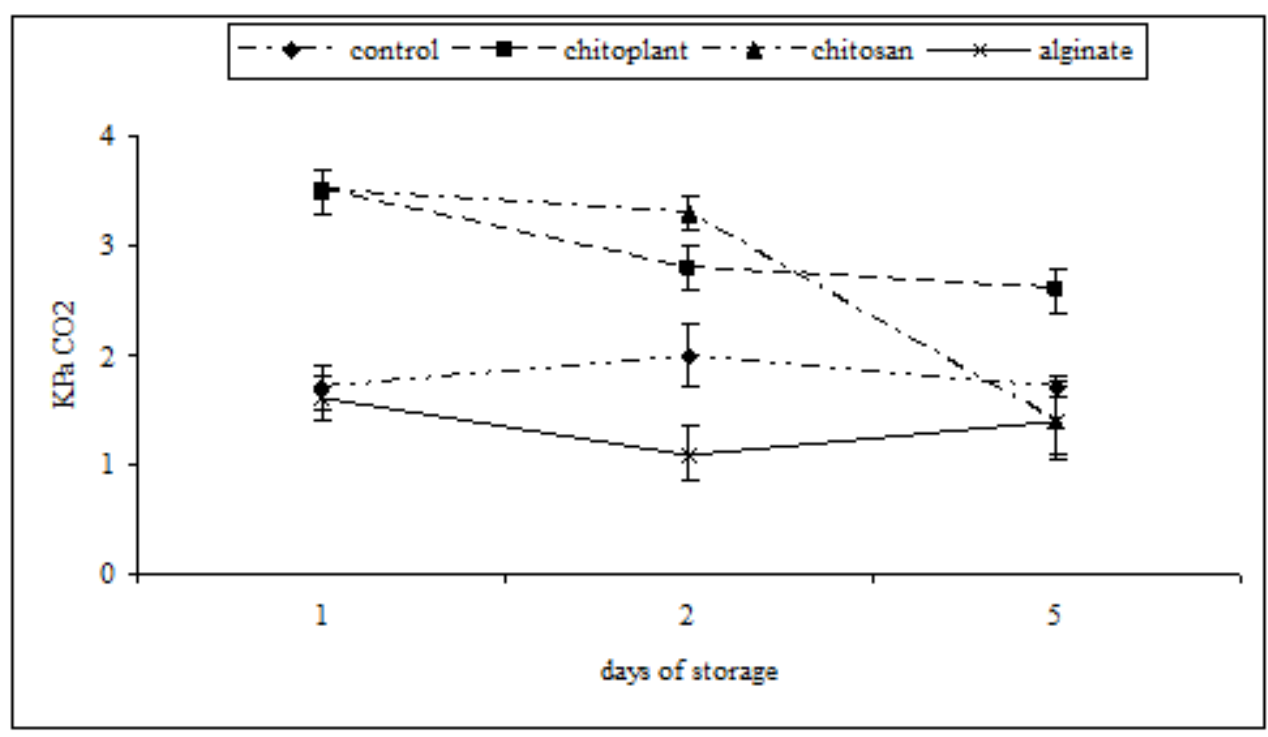

Fig. 3. Evolution of color (Hue angle) during cold storage on nectarines coated with Chitoplant ${ }^{\circledR}$ (20 $\mathrm{g} / \mathrm{L})$, chitosan $(20 \mathrm{~g} / \mathrm{L})$ and sodium alginate $(20 \mathrm{~g} / \mathrm{L})$. Data are the mean $\pm \mathrm{SE}(\mathrm{n}=25)$.

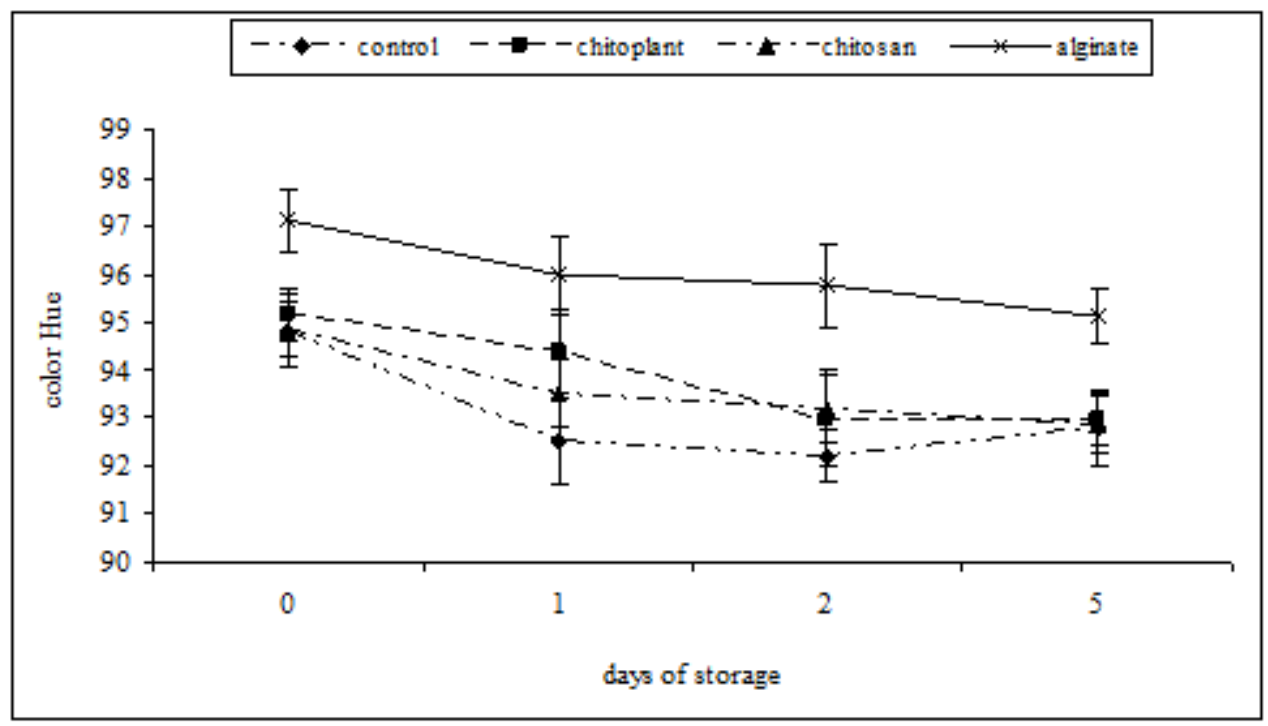


Fig. 4. Evolution of color $\left(\mathrm{L}^{*}\right)$ during cold storage on nectarines coated with Chitoplant ${ }^{\circledR}(20 \mathrm{~g} / \mathrm{L})$, chitosan $(20 \mathrm{~g} / \mathrm{L})$ and sodium alginate $(20 \mathrm{~g} / \mathrm{L})$. Data are the mean $\pm \mathrm{SE}(\mathrm{n}=25)$.

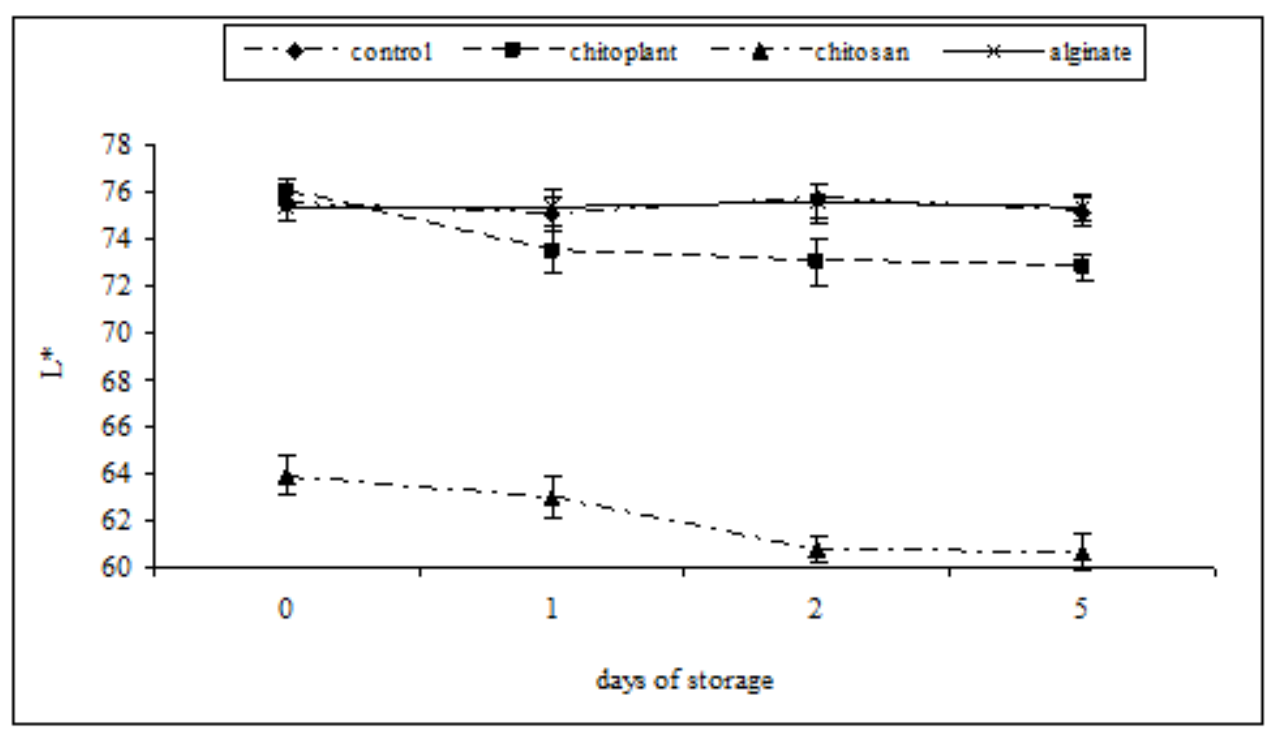

Fig. 5. Evolution of color $\left(b^{*}\right)$ during cold storage on nectarines coated with Chitoplant ${ }^{\circledR}(20 \mathrm{~g} / \mathrm{L})$, chitosan $(20 \mathrm{~g} / \mathrm{L})$ and sodium alginate $(20 \mathrm{~g} / \mathrm{L})$. Data are the mean $\pm \mathrm{SE}(\mathrm{n}=25)$.

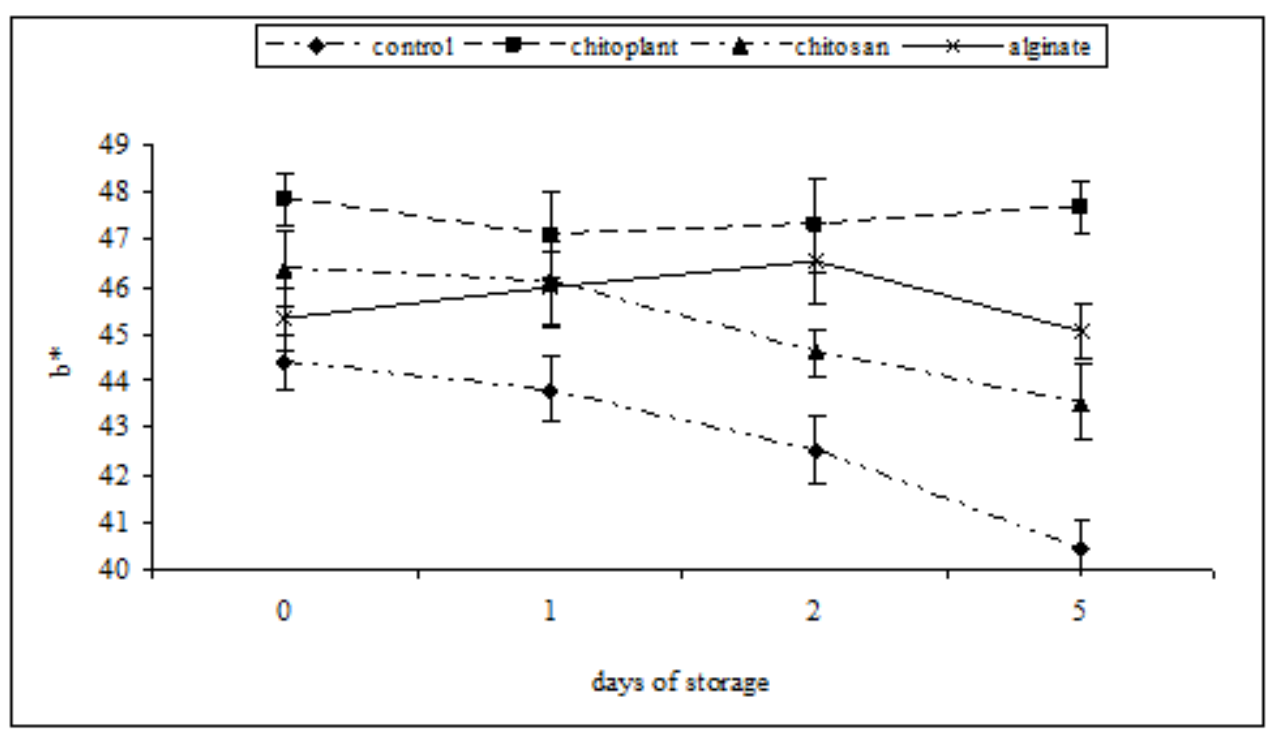


Fig. 6. Evolution of color (Whiteness Index) during cold storage on nectarines coated with Chitoplant $^{\circledR}(20 \mathrm{~g} / \mathrm{L})$, chitosan $(20 \mathrm{~g} / \mathrm{L})$ and sodium alginate $(20 \mathrm{~g} / \mathrm{L})$. Data are the mean $\pm \mathrm{SE}$ $(n=25)$.

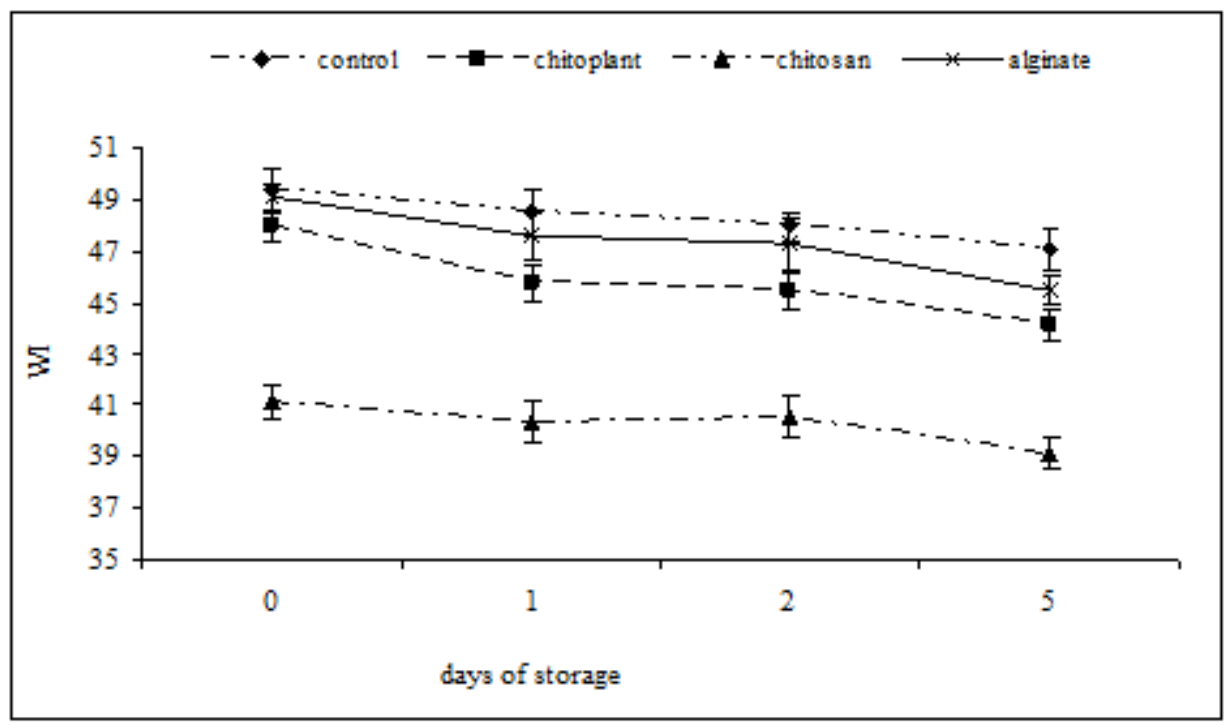

Fig. 7. Browning Potential values during cold storage on nectarines coated with Chitoplant ${ }^{\circledR}$ (20 $\mathrm{g} / \mathrm{L})$, chitosan $(20 \mathrm{~g} / \mathrm{L})$ and sodium alginate $(20 \mathrm{~g} / \mathrm{L})$. Data are the mean $\pm \mathrm{SE}(\mathrm{n}=25)$.

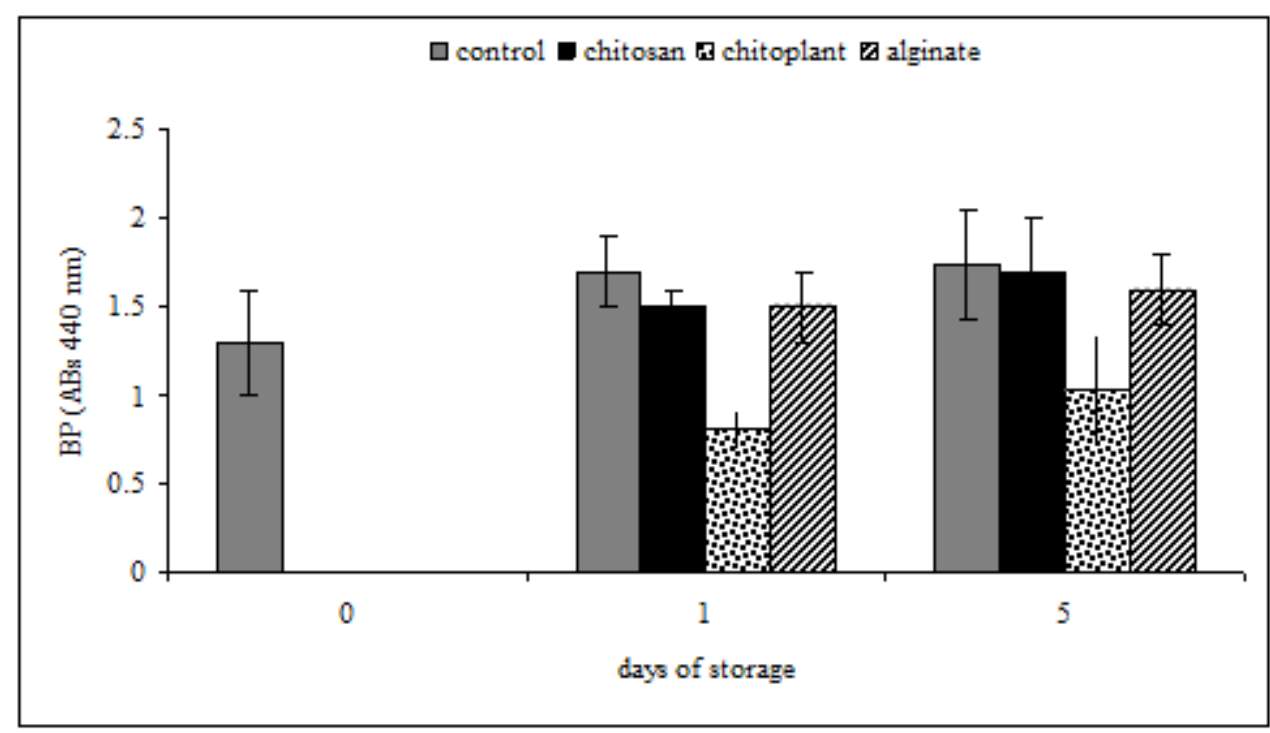

